Original article

\title{
SOME NEW EVIDENCE FOR THE KHOIAK FEAST AT THEBES
}

\author{
Abou Zaid, O. \\ Egyptology dept., Faculty of Archaeology, Aswan Univ., Aswan, Egypt \\ E-mail: Omarabouzaid76@gmail.com
}

\begin{abstract}
This article is based on the author recent discovery of the Osirian catacomb of Qurnet Murai at Thebes (Abou Zaid, O., A New Discovery of Catacomb in Qurnet Murai at Thebes. BIFAO 117 (2017) pp. 9-24, Pls. 1 [a-d] - 3 [a-c]). Many texts and reliefs from Thebes illustrate the Khoiak feast, but there is no real evidence for where this event took place in the Theban region. The new discovery of the Osirian catacomb has revealed the actual site where this feast was celebrated. In this paper, therefore, I will propose the route of this feast according to the new discovery of the catacomb, comparing it with festival routes of similar places, such as Abydos (the route from the temple to the tomb), along with various aspects of the Dendara enactment of the feast.
\end{abstract}

Keywords: Khoiak feast, Ptah, Sokar, Osiris, Route, Osirian, Catacomb, Shetayt, Episode

\section{Introduction}

Khoiak is the Coptic name of the fourth month, extending from the middle of October to the middle of November, equivalent to the fourth month of "3ht" (inundation season) [1]. The name is derived from the ancient Egyptian term “k3 $h^{\prime} k_{3}$ " feast dates back to the archaic period, at which time the Sokar festival took place at Memphis [3], and it is also depicted in tombs from the late old kingdom through the end of Egyptian history, as attested by examples at Beni Hassan, Meir, Assuit, Abydos and Aswan [4]. The first indication of this feast occurred in the Pyramid texts; was an important part of Egyptian religion in the middle kingdom, and then in the new kingdom the Sokar celebration and the raising of the djed-pillar became the central episode of the Khoiak feast. In the Greco-Roman period, this feast occurred from $12^{\text {th }}$ to $30^{\text {th }}$ of Khoiak, and it is recorded in inscriptions at Dendara, Edfu, and Philae in addition to texts on papyrus [5]. But both the middle kingdom and the Ptolemaic period [The time of the new catacomb discovered at Qurnet Murai] yield source material for the Khoiak feast [6]. During the GreekRoman times, the feast of Sokar took place on the last day of the Osirian celebration specifically on the $26^{\text {th }}$ of the fourth month of the inundation season [7]. Both Osiris and Sokar were funerary gods, and the popularity of their festivals is attested at an early date; the Sokar feast is mentioned on Palermo stone from the $5^{\text {th }}$ dynasty, and the identification of Osiris, Sokar, and Ptah dates back to this period at Memphis [8] which presaged their complete fusion in the Ptolemaic period [9]. Although Osiris was the god of the dead, the statue of Sokar, one of main focal points of the Khoiak feast recalled the dismembered body of the murdered Osiris, whose limbs were collected by his wife Isis and rejoined in the form of Sokar [5]. During the middle kingdom, the Khoiak 
feast was held for the goddess Hathor, while in late period it was also celebrated for Horus at Edfu. But the

\section{Main Sources of Khoiak Feast}

Although the Dendara chapel text record eight nomes of upper Egypt and twelve of lower Egypt as participating in the Khoiak feast [5], the Theban nome "W3st" was not included. At Medinet Habu there is a list, carved in imitation of a Ramasseum list [11], as well as temple scenes from Deir el-Medina [4]. Some Theban tombs contain representations of Khoiak festival scenes (TT45, TT50, TT65, TT68, TT78, TT178, TT409). Additional evidence is found in several ostraca from Deir elMedina (BM 29560=5639a; Berlin 14214, 11; DeM 1265) [12], Louvre N 3176 [13]. Papyrus Jumilhacis a record of mythological and religious events, dating to the Ptolemaic period (100 B.C.) [13] and is the only source that coincides with the newly discovered catacomb. The funerary papyrus Louvre N 3176 descr-

\section{Main Aspects of Khoiak Feast}

The Khoiak feast was a dramatic episode that the courage, loyalty and devotion of Isis on the part of Osiris after his death [5]; where the god Osiris was brought from his temple (Hwt-ntr . Wsir hnti-imntiw) to his tomb at Peker $(p k r)$ [15]. This feast included considerations of life and death reflected in a dramatic performance, including song, dance, dialogue, and monologue concerning the legend of Osiris and Seth [5, 6]. Sokar and his Khoiak feast became a part of the Osirian festival during the same month. This aspect of the feast dealt with the death and resurrection of Osiris, wherein the Sokar statue represented the god Osiris after his dismemberment [4]. In fact; there is no document giving the content of the festival in its entirety; rather it must be reconstructed from various texts. The existing mythical dramatic texts are isolated from each other and must be arranged according to the sequence of the Osirian festival episodes. The myth- main beneficiary of the feast of Khoiak was Osiris, both in the late period [10] and in the Greco-Roman period [6].

ibes the rites for Osiris at Karnak where the relevant Osiris Khoiak chambers are located [Osirian Catacomb] [13]; these may be dated to the reign of Ptolemy IV [14]. Among many inscribed Ostraca from Deir el-Medina containing the sequence of monthly feasts names and their occurrences, there are two that mention the Khoiak feast (British Museum 29560 "col.18" and Berlin 12406 "11") [12]. It is thus possible that, Deir el-Medina could be associated with the site where the Khoiak feast took place, and it may be that there is some connection between the Qurnet Muraicata comb and Deir elMedina in relationship to this feast. Another main source on the Khoiak feast are Book of the Dead in Chapters; 1, 15, $74,110,138,142$ and 148 [15].

ological material covers a period from the middle kingdom (the stela of Ikhernofret, Berlin 1204, which contains the most complete textual description of its processional equipment) [15] to the Ptolemaic period [6]. There were six main items used during the festival [8]:

1) A tub in which the molds were put.

2) The mold of Khenty-Imenty.

3) The mold of Sokar.

4) A double basin for forming the part of the god's body belonging to each particular city.

5) A mold for forming a cake of bread to be offered by each city.

6) An Osiris sarcophagus.

Beside these, 34 barks which were prepared to carry 34 mummies of the god, and the same number of divinities who accompanied them [8]. The feast started on the $12^{\text {th }}$ day of Khoiak, with the watering of the Osiris molds, and ended on day 30 of same month, with the raising of the djed-pillar; this ritual 
appears in Medinet Habu calendar, lines 1163-1190 [16]. Among the main events were the opening of the aperture in Shetayt shrine on day $21[16,17]$ and making way in Shetayt shrine on day 23 [13]. The main event of this feast was the hoeing of the earth [3], according to the illustration for the $18^{\text {th }}$ chapter of the Book of the Dead [18], while the main event of Osiris Khoiak festival was "mysteries of Osiris"[3], which was followed by the Sokar celebration on the $26^{\text {th }}$ day of the month [7]. This involved the five daughters of Re (Hathor, Wadjet, Sekhemet, Shesemet, and Bastet) and five birds according to the complete episode as depicted on the second court (south and south-west inner walls) of the mortuary temple of Ramesses III at Medinet Habu $[19,20]$ in addition to a celebration of the rebirth of Osiris after his death and the defeat of his enemies by his son, the king acting as Horus [3]. Various aspects of the Khoiak feast were inscribed in the well-known chapel on the roof of the temple of Dendara. The rites began with making the figures of Osiris, continuing with their burial and the raising of the djed-pillar, details are given concerning the molds, the substance out of which the figures are formed (including figures of Osiris, the Ennead -associated with him-, Wepwawet, and sacred boats,

\section{Results}

The southern entrance of Amenhotep III's mortuary temple at Thebes, facing Medinet Habu could possibly have been the main axis of approach for the dramatic Khoiak festival procession from the mortuary temple to Malqata, passing $18^{\text {th }}$ dynasty temple of Medinet Habu. Relating to this temple, it is worth noting that the god Sokar was significant within the Akhmenou in Karnak, constructed during the reign of Thutmose III [26]. During the remaining episode of the feast, the Shetayt was built. The site of Wadi Qubbanet el-Qirud, the "Valley of the tombs of the monkeys" [27] beyond the valley of queens and to the west of Medinet Habu, has yielded four pieces of Osiris and Sokar figures, dating to the new kin- sledges and shrines) [3]. Also described are the methods whereby, the figures were to be dried, decorated, clothed and buried. These procedures represent the main aspects of what happened on the various days of the festival, from $12^{\text {th }}$ of Khoiak to the end of the month [6]. One of the main components of Khoiak festival was the "Osiris bricks" which had become smaller than those used previously [21,22]. The mummiform figures of Osiris [22] and of several deities as Sokar were a symbol of their attributes as gods of death and afterlife [23]. Each year in the days leading up to the Khoiak feast, new figures of Osiris and Sokar were made of soil and grain in molds and some tomes called "corn mummies" [15-21]. Related to this procedure is BD Spell 142 (S.1), which describes Osiris as Sokar, while the Sokar feast occurs in Spell 190 (P2) [24]. A good example of these Osiris corn mummies is Boston museum of fine arts 72.4819 , dating to the late period, which is made of sand and grain and wrapped in linen [3]. These objects were usually decorated with gold foil or placed in coffins decorated with gold foil [15]. Osiris was considered to be a spirit of vegetation [25], and in the late period these corn mummies were buried in falcon headed coffins inscribed with the name of Sokar and with BD Spell 15 [15].

gdom, which may be related to the Khoiak feast at Thebes [22] Osiris figures may have been buried in this valley because of the role of the baboon in the resurrection of the body of Osiris [27]. All of these sites in the southern part of western Thebes are indicative of the religious importance of this district during the new kingdom. In texts from the late and Ptolemaic periods such as the Bremner-Rhind Papyrus, the Shetayt shrine was considered to be the place in which Osiris was buried, and it was also called the shrine of Sokar [4]. At Karnak the entire site around the Osirian catacomb located at the northeast corner of the Amun precinct was called "st $3 t$ the great place" [28]. It may also be that, the catacomb of Qurnet Murai 
and its surrounding area had its own sacred name. The original plan of this complex had a forecourt, an elongated passage, and an inner chapel, classified according to Kampp as type IIb [29,30] and the loculi are same as the ones in the Karnak Catacomb, which dates to the reign of Ptolemy IV. Therefore, the new Osirian catacomb could represent the "štyt tomb, sign $\mathrm{O} 160$

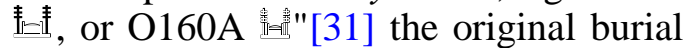
place of Osiris, as mentioned in various sources. The myth was re-enacted in various nomes, so the Shetayt functioned as a mythical visualization of the Osirian tomb in the framework of the Osirian mysteries [5, $6,32]$. The western side of the hill of Qurnet Murai was closely associated with Deir el-Medina [33], where two sanctuaries of Ptah-Sokar-Osiris are located to the right and left of the main sanctuary of Hathor, added by Ptolemy IV "Philopator" $[4,30]$ inside the Ptolemaic temple. These structures, however, might date to slightly earlier or later than the construction of the Qurnet Murai catacomb. These two sanctuaries, juxtaposed with the newlydiscovered Osirian catacomb, may relate
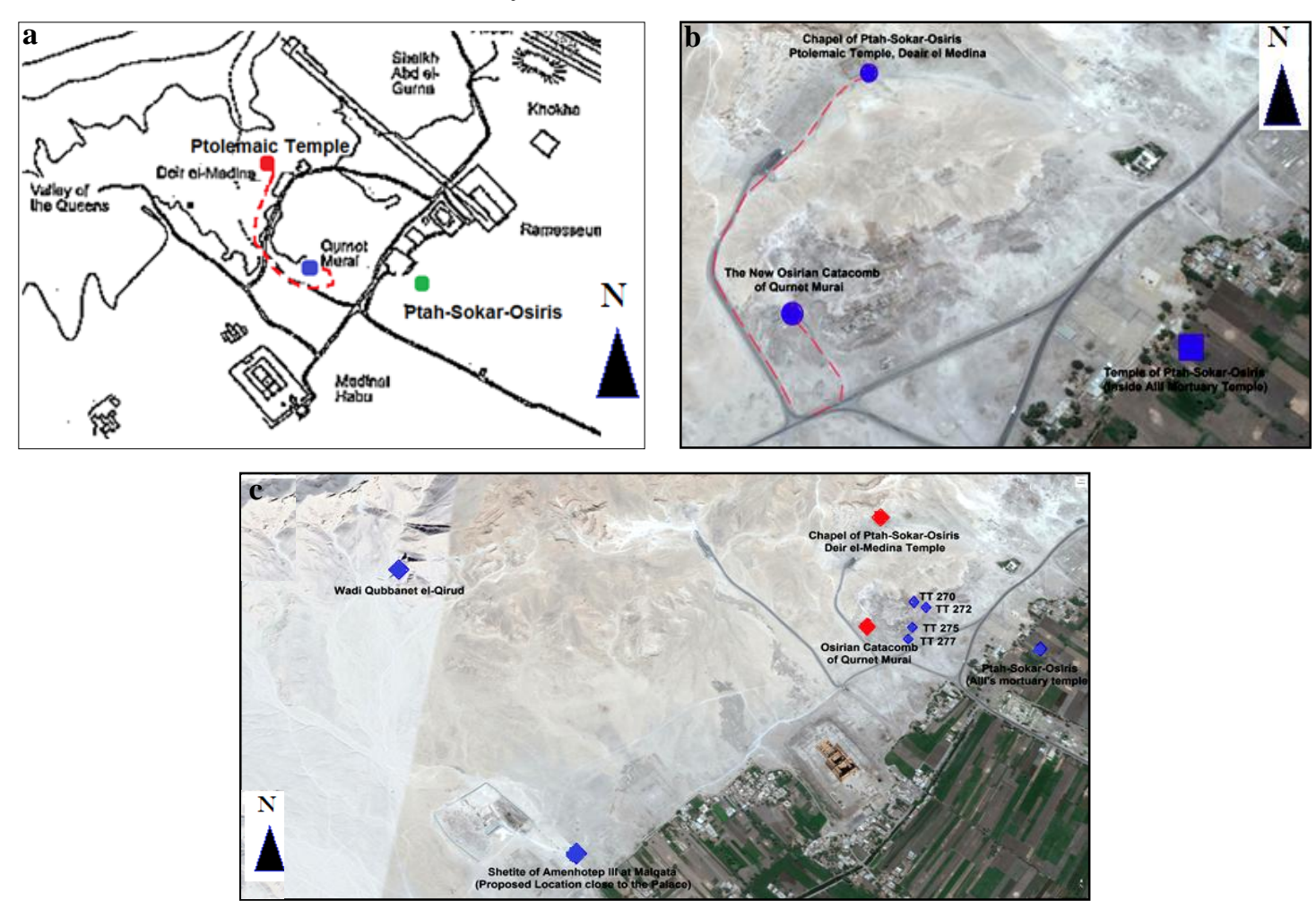

Figure (1) Shows a. proposal for start and end points of the main route of the Khoiak feast, without to the beginning and the end of this dramatic festival, which could have processed from Deir el-Medina to Qurnet Murai, fig. $(1-a, b)[34,35]$. It should be remembered, however, that the beginning and end points do not represent the whole dramatic arc the Khoiak episode, as various components took place in different sites during the days of this festival, as at Abydos [15] and Dendara [5]. It is possible that this proposed route represents part of the context of this feast in Ptolemaic Thebes. We conjecture that Ptolemy VI dedicated the two sanctuaries of Ptah-Sokar-Osiris in the Deir el-Medina temple for Khoiak feast. The context of this feast in the new kingdom was of course different, with the temple of Ptah-Sokar-Osiris perhaps inside the mortuary temple of Amenhotep III [26], and with the shetayt of Amenhotep III at Malqata [26] and Wadi Qubbanet el-Qirud [22]. Additional excavation and survey works in the southern part of Thebes will be needed in order to find out more about this episode of the Khoiak festival, fig. (1-c).

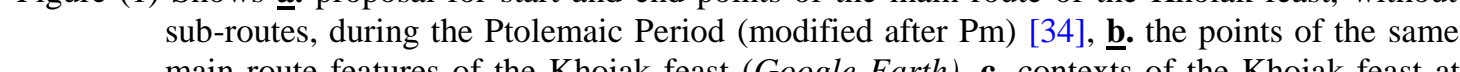
main route features of the Khoiak feast (Google Earth), $\mathbf{c}$. contexts of the Khoiak feast at

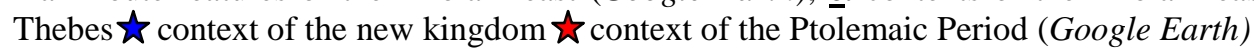




\section{Discussion}

During the feast, the god Osiris was brought from his temple to his tomb along a sacred route [15]. At Sais, Herodotus described a sacred routes for the Khoiak feast around the lake of the Neit temple [5]. At Abydos, during the Middle Kingdom, this feast was started by bringing the god Osiris from his temple to his tomb, a destination for pilgrims from all over Egypt to come and see the procession and to set up stelae and statues in offering chapels along its route [15]. Later, the syncretization of Osiris, Sokar and Ptah, led to the production of figures of Sokar-Osiris and Ptah-Sokar-Osiris, one of the main forms of Osiris during the Khoiak feast. The calendar of Ramesses III at Medinet Habudoes not specifically indicate the Osirian festival of Khoiak, but it lists the rites of the Memphite Ptah-Sokar, including the raising of the djed-pillar [21], There are four types of Ptah-Sokar-Osiris statues, differentiated according to their function and location inside the tomb [23], which were part of the feast. From the New Kingdom, this feast took place from $18^{\text {th }}$ to the $30^{\text {th }}$ of Khoiak month [36]. At Thebes, many inscriptions of the god Sokar occur in tombs (TT45, TT50, TT65, TT68, TT78, TT178, TT409) and the ban temples, such as: Ramasseum and Medinet Habu [37]. Although there are some tombs for priests of Sokar in Sheikh Abdel Qurna (TT 249, TT 341, TT 384), and in Deir el-Medina (TT 323) during the new kingdom, tombs of the members of this priesthood were concentrated at Qurnet Murai, fig (1-c \& 2): * TT 270: Amenemwia (Wab priest) and lector-priest of Ptah-Sokar, Dyn. 19 [26, 34]. * TT 272: Khaemopet, Lector-priest in the temple of Sokar, Ramesside period [26, 34]. * TT 275: Sobekmosi, divine father in the temples of Amenhotep III and of Sokar, Ramesside [26,34]. * TT 277: Imneminet, divine father in the Mansion of Amenhotep III, Ramesside period [26,34]. In this tomb, there is evidence for five priests of Sokar-Osiris including (the "wab" priest Djeser, "Sempriest"Minmose, "sokar priest"
Ptahmose, an unnamed "wab priest" and unnamed "Ptah-Sokar priest" [26]. A small temple of Ptah-Sokar-Osiris, which probably dates originally to the middle kingdom and which Amenhotep III included in his mortuary temple [26] was located to the south of the northern gate of that temple complex at Kom el-Hittan. Built of limestone along a north-south axis and facing north it, signified the god's association with the king's mortuary cult and his jubilee celebrations. This small temple was connected with the northern gate by a paved path and was oriented in the direction of Memphis, whence the Sokar cult was imported to Thebes [26]. After the temple of Amenhotep III was destroyed by an earthquake, Merenptah dismantled some of Ptah-Sokar-Osiris temple's blocks and incorporated them into his temple. From the time of Merenptah, however, no priests of the PtahSokar-Osiris temple are attested [26]. We may conjecture that the route of the Khoiak feast in the middle kingdom could have used this small temple as starting point, proceeding either towards the Muntohotep II temple at Deir el-Bahari or to the middle kingdom shrine in Madinet $\mathrm{Habu}$, whose foundations were discovered underneath the $18^{\text {th }}$ dynasty temple of Amun. On the foot of a quartzite osiride statue of Amenhotep III in the west hall of the great court of his mortuary temple, Sokar is described as "Sokar, Lord of the Shetayt" while Amenhotep III, on the belt of his northern colossus (the colossus of Memnon), is described as "Beloved of Sokar" on the back pillar of the southern colossus he is also called "Beloved by Amun-Re and Sokar" [26]. It is thus possible that a complete route for the Khoiak feast existed in the vicinity of the mortuary complex of Amenhotep III and the jubilee palace at Malqata, where texts also mention the shetayt [26].indeed, the small temple of Ptah-Sokar-Osiris could have played, a role assumed by the temple of Deir elMedina in Ptolemaic and Roman times. 


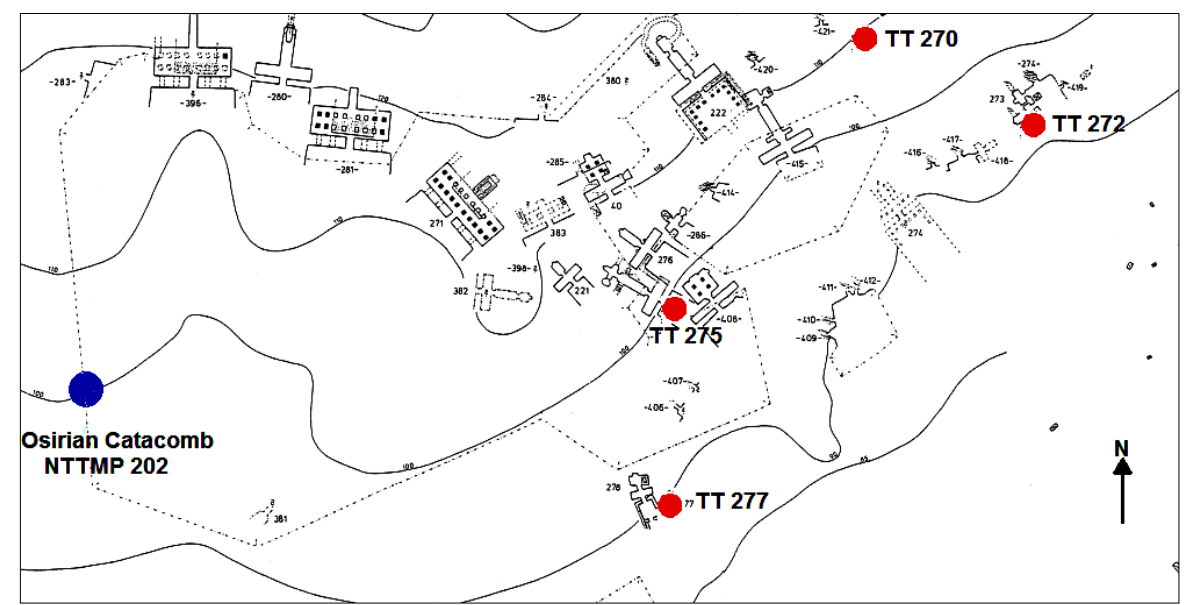

Figure (2) Shows location of the tombs of Sokar-Osiris priests at Qurnet Murai (modified after Kampp) [29].

\section{Conclusion}

The political and religious prestige of Thebessuggests an investigation of the routes of the Khoiak feast, particularly considering cult-topographical features such as the Ptah-Sokar-Osiris temple inside the mortuary temple of Amenhotep III, the shetayt shrine of Amenhotep III and Osiris figures from Wadi Qubbanet el-Qirud, and the tombs of the priests of Ptah-Sokar-Osiris at Qurnet Murai. These locations may represent the context of this feast during the New kingdom. The newlydiscovered Osirian catacomb of Qurnet Murai may in fact have served as the end point of the Khoiak festival procession. If so, one must inquire as to the location of the temple that served as the starting point of this procession. Indeed, the destruction of Amenhotep III's mortuary temple complex and the dismantled blocks of the Ptah-Sokar-Osiris, re-used by Merenptah in his own mortuary temple, suggests another site dedicated to Ptah-Sokar-Osiris. An answer may be proposed based on the dating of the Osirian catacomb to the Ptolemaic period, alongside two sancturies inside the Deir el-Medina temple dedicated to this god in the time of Ptolemy IV. We conclude that the topographical context of the Khoiak festival in Thebes had shifted significantly from the new kingdom to the Ptolemaic period.

\section{References}

[1] Parker, R., (1950). The calendar of ancient Egypt. SAOC 26. Chicago.

[2] Černy, J. (1958). Some Coptic etymologies III, BIFAO, Vol. 57, pp: 203-213.

[3] Teeter, E. (2011). Religion and ritual in ancient Egypt, Cambridge Univ. Press, UK.

[4] Mikhail, L, (1984a). The festival of Sokar: An episode of the Osirian Khoiak festival, GM, Vol. 82, pp: 25-44.

[5] Chassinat, É., (1966). Le mystère d'Osiris au mois de Khoiak, Vol. I, PIFAO, Cairo.

[6] Mikhail, L., (1984b). Dramatic aspects of the Osirian Khoiak festival: An outline, GM, Vol. 81, pp: 29-54.

[7] Faulkner, R., (1937). The BremnerRhind papyrus II, JEA, Vol. 23 (1), pp: 10-16.
[8] Bakry, H., (1955). The main elements of the Osiris legend with reference to Plutarch and certain folk-tales, Durham Univ., http:// etheses.dur.ac.uk/9519/ (22-4-2018).

[9] Bielesch, S., (2011). O Festival de Khoiak: A celebração dos ciclos do Renasciento, Revista Angelus Novus, Vol. 2, pp: 5-33.

[10] Daumas, F., (1975). Choiakfest, in; Helch, W. \& Otto, E. (eds.) Lexicon der Aegyptologie. Vol. 1, Otto Harrassowitz, Wiesbaden, pp: 958-960.

[11] Spalinger, A., (1992). Three studies on Egyptian feasts and their chronological implications, Halgo, Maryland.

[12] Van Walsem, R, (1982). Monthnames and feasts at Deir el-Medîna, in: Demaree, R. \& Janssen, J. (eds.) Gleanings from Deirel-Medîna I, Nederlands instituut voor het nabije oosten te Leiden, pp. 215-244. 
[13] http://www.ucl.ac.uk/museumsstati c/digitalegypt/ideology/khoiak.htm 1 (13-10-2018).

[14] Coulon, L., Leclère, F. \& Marchand, S., (1993). "Catacombes" Osiriennes de Ptolémée IV à Karnak: Rapport préliminaire de la campagne de fouilles, $C d K$, Vol. 10, pp: 205-237.

[15] Eaton, K., (2006). The festivals of Osiris and Sokar in the month of Khoiak: The evidence from nineteenth dynasty royal monuments at Abydos, $S A K$, Vol. 35, pp: 75-101.

[16] Nelson, H., (1934). The calendar, the "slaughterhouse" and minor records of Ramses III: The epigraphic survey, Medinet Habu, Vol. 3. OIP 23, University of Chicago Press, Chicago.

[17] Murnane, W., (1980). United with eternity. A concise guide to the monuments of Medinet Habu, AUC Press in Cairo.

[18] Naville, E., (1886). Das Aegyptische Totenbuch der XVIII bis XIX dynastie, Vol. 1. Verlag von A. Asher \& Co, Berlin.

[19] Graindorge-Héreil, C., (1996). La Quête de la lumière au mois de Khoiak: Une histoire d'Oies, JEA, Vol. 82, pp: 83-105.

[20] Wilson, J. \& Allen, T., (1940). Festival scenes of Ramses III: The epigraphic survey, Medinet Habu, IV. OIP 51. University of Chicago Press, Chicago.

[21] Tooley, J., (1996). Osiris bricks. JEA, Vol. 82, pp: 167-179.

[22] Saragoza, F., (2009). L' Acéphale et le ritual Osirien de Khoiak. À propose de quatre pièces découvertes au quadi koubbanet el-qouroud, Egypte, Afrique \& Orient, Vol. 55, pp. 51-66.

[23] Raven, M, (1978-9). Papyrus-sheaths and Ptah-Sokar-Osiris statues, OMRO, Vol $_{\mathrm{s}}$. 59-60, pp: 251-296.

[24] Allen, T., (1974). The book of the dead or going forth by day, ideas of the ancient Egyptians concerning the hereafter as expressed in their own terms, SAOC 37. University of Chicago Press, Chicago.
[25] Bates, O., (1915). The name Osiris, JEA, Vol. 2 (4), pp: 207-208.

[26] Haeny, G., (1981). Untersuchungenim totentempel Amenophis' III, beitraegezur Aegyptischen bauforschung und altertumskunde, Heft 11, Wiesbaden, Germany

[27] Centrone, M., (2006). Choosing the Burial Place for Corn Mummies: A random selection?, in, Dann, $\mathrm{R}$, (ed) Proc. of the $5^{\text {th }}$ Annual Sym., Current Research in Egyptology 2004, University of Durham, Oxford, pp. 26-29.

[28] Coulon, L. (2008). Le tombeau d'Osiris à travers les texts magiques du nouvel empire, in: Gallois, Ch., Grandet, P. \& Pantalacci, P. (eds.) Mélanges offerts à FranÇois Neveu, par sesamis, éléves et collègues à l'occasion de son soixante-quinzième anniversaire, Bibliothèque d'ètude, IFAO, pp:73-82.

[29] Kampp, F. (1996). Die Thebanische nekropole, zum wandel des grabgedankens von der XVIII, biszur XX. Dynastie, Vol. I. Verlag Philipp von Zabern, Mainz.

[30] Wilkinson, R. (2000). The complete temples of ancient Egypt, Thames \& Hudson, London.

[31] Hannig, R. (1995). Großes handwörterbuch Ägyptisch-Deutsch (2800950 v. Chr): Die sprache der pharaonen, Verlag Philipp von Zabern, Mainz.

[32] Erman, A. \& Grapow, H., (1971) Wörterbuch der Aegyptischen sprache, Vol. IV. Akademie-verlag, Berlin.

[33] Strudwick, N., (2003). Some aspects of the archaeology of the Theban necropolis in the Ptolemaic and Roman Period, Strudwick, in: Taylor N. (ed.), The Theban necropolis. past, present and future, British Museum Press. London, pp. 167-188.

[34] Porter, B. \& Moss, R., (1960). Topographical bibliography of ancient Egyptian hieroglyphic texts, reliefs, and paintings, Vol. I, The Theban Necropolis. Part I. Private tombs, $2^{\text {nd }}$ ed., Griffith Institute, Oxford. 
[35] Johnson, W., (1998). Monuments and monumental art under Amenhotep III: Evolution and meaning', in: O'Connor, D. \& Cline, E. (eds), Amenhotep III: perspectives on his reign. University of Michigan Press, USA, pp.63-94.
[36] Altenmüeller, H., (1975). Feste, in: Helch,W. \& Otto, E. (eds) Lexicon der Aegyptologie. Vol. II, Otto Harrassowitz, Wiesbaden, pp. 171-191.

[37] Graindorge-Héreil, C. (1994). Le dieu Sokar à Thèbes au nouvel empire, Vol. 2, Goettinger Orientforschungen, Wiesbaden. 